\title{
Surface carcinoma of the stomach
}

\author{
M. K. MASON ${ }^{1}$ \\ From the Department of Pathology, King's College Hospital Medical School, \\ London
}

EDITORIAL SYNOPSIS Surface carcinomata confined to the mucosa have been found in $10 \%$ of stomachs operated on for apparently benign conditions. A multifocal origin is not uncommon. The prognosis is good. In this series the diagnosis was established by pathological studies on resected specimens but an increased awareness of this possibility may alert clinicians to make the diagnosis before operation.

The majority of patients who present with a gastric carcinoma have a large growth which can be diagnosed with comparative ease, both by clinical procedures and by naked-eye inspection of the excised stomach. There is, however, a group of cases in which the growth is confined to the mucosa and, in the absence of an obvious tumour, the diagnosis can only be made by microscopic examination. The lesions have been studied by several authors (Ewing, 1936; Gutmann, Bertrand, and Péristiany, 1939; Mallory, 1940; Stout, 1942; Bamforth, 1955; Friesen, Dockerty, and ReMine, 1962) who have applied a variety of names but the most satisfactory term is probably 'superficial' or 'surface' carcinoma. Their particular importance lies both in the good prognosis and also in the information they provide on the pathogenesis of gastric cancer. The following series of cases is presented to show the incidence and pathological features of the condition.

\section{MATERIALS AND METHODS}

A total of 158 stomachs surgically removed by partial gastrectomy for apparently benign conditions were obtained fresh, opened along the greater curvature and pinned out flat on a cork board. Cytological studies were undertaken on the unfixed mucosa by scraping it in various areas with a toothbrush and spreading the material obtained onto a slide. Care was always taken to obtain a smear from the vicinity of any ulcer. The smears were fixed while still wet in Schaudinn's solution and stained with haemalum and eosin. The stomachs were then fixed on the cork board for 24 hours in formol saline. The entire lesser curvature was then sectioned using the 'swiss roll' technique of Magnus (1937), and stained with haematoxylin and eosin. Sections were also taken from any ulcers situated away from the lesser

'Present address: Department of Pathology, St. James's Hospital, Leeds. curve and from representative areas of the pyloric and body mucosa. Eight surface carcinomas were discovered by this means. When one of these lesions was found, it was mapped out and its size determined by taking further sections in a plane at right angles to the lesser curve as shown in Fig. 1, which illustrates the findings in case 1. A search was also made along the greater and lesser curvatures in all specimens for lymph nodes and sections taken of all those found.

An additional four stomachs with surface carcinomas became available later and were examined in a similar way. Finally, a search through earlier gastrectomy specimens revealed three more stomachs in which surface carcinomas were present but these were not available for further sectioning.

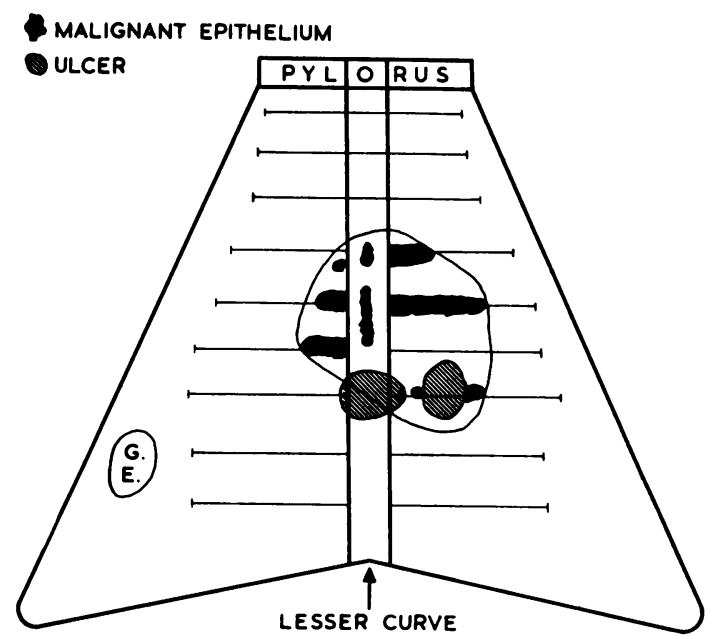

FIG. 1. Method of sectioning a stomach and mapping out a surface carcinoma (case 1). 


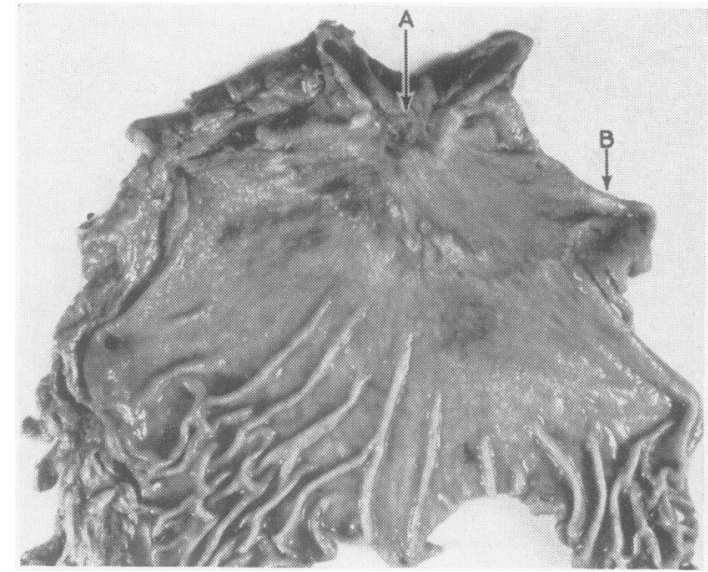

FIG. 2. A stomach, opened along the greater curve, showing a prepyloric ulcer $(A)$. The pyloric mucosa proximal to it is smooth where there is surface carcinoma and clearly delineated from the normal by a nodular line (B) (case 9).

\section{PATHOLOGY OF SURFACE CARCINOMAS}

MACROSCOPIC FEATURES Surface carcinomas cannot be recognized by naked-eye inspection but there may sometimes be non-specific mucosal changes which arouse suspicion. These mainly take the form of a thinning and smoothness of the mucosa, while in some cases small nodules may be visible (Fig. 2) or the mucosa may appear roughened. Gastric ulceration is nearly always present and only two stomachs did not show this feature. The ulcer may be either a primary malignant one or it may be a pre-existing benign ulcer.

HISTOLOGICAL APPEARANCES The characteristic feature of these neoplasms is the more or less extensive involvement of the mucosa without deeper invasion. The diagnosis of carcinoma depends therefore on finding a loss of the normal mucosal pattern which is partially or completely replaced by cells showing malignant characteristics. Both the glandular and interstitial tissue are replaced by growth. The whole thickness of the mucosa is usually involved but quite commonly carcinoma is present in the superficial portion only or, less often, in the middle or deepest portion (Figs. 3-5). There may be minute areas of early invasion, with growth extending beneath the muscularis mucosae (Fig. 6). The individual cells show the usual features of malignancy, being enlarged and hyperchromatic with prominent nucleoli: mitoses are also present. Cytological examination of the cells obtained by scraping the stomach (Fig. 7) further demonstrates

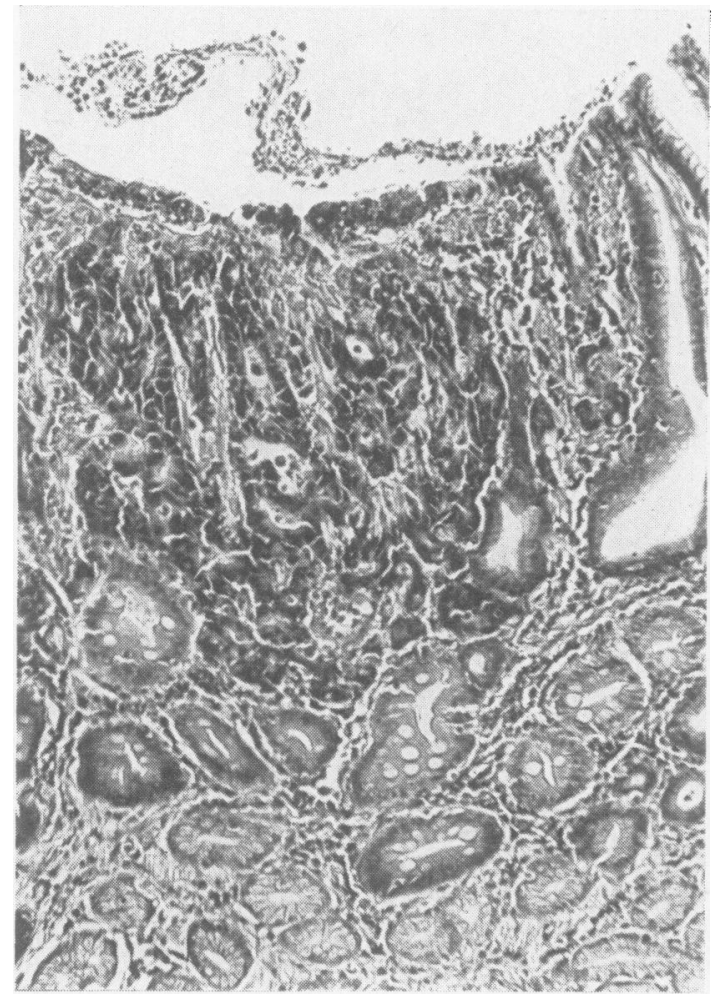

FIG. 3. Surface carcinoma involving the superficial portion of the mucosa only. There is adjacent intestinal metaplasia $($ case 1$)(\times 145)$.

that the malignant cells from these tumours are identical to those obtained from obvious carcinomas. Histologically, the tumours are mostly adenocarcinomas, while some are undifferentiated spheroidal cell tumours. Mucoid areas are common and may be extensive (Fig. 8).

AREA OF LESION The size of the lesions in individual cases is summarized in Tables 1 and 2 . In this series, the areas involved varied from $7.0 \times 8.0 \mathrm{~cm}$. to $3.5 \times 3.0 \mathrm{~cm}$. in their maximum dimensions. Mapping out these stomachs showed that in the majority of cases the lesion was clearly arising in a number of separate foci in the affected area (Fig. 1). It was exceptional for an entire area of mucosa to show surface carcinoma without any free areas.

ULCERATION An ulcer was present in all but two of the stomachs in this series. This feature is of great importance as it separates into two groups the type of case in which a surface carcinoma may be found. In the first group (Table I) the lesion develops in a stomach in which there is already a benign ulcer. In this group 


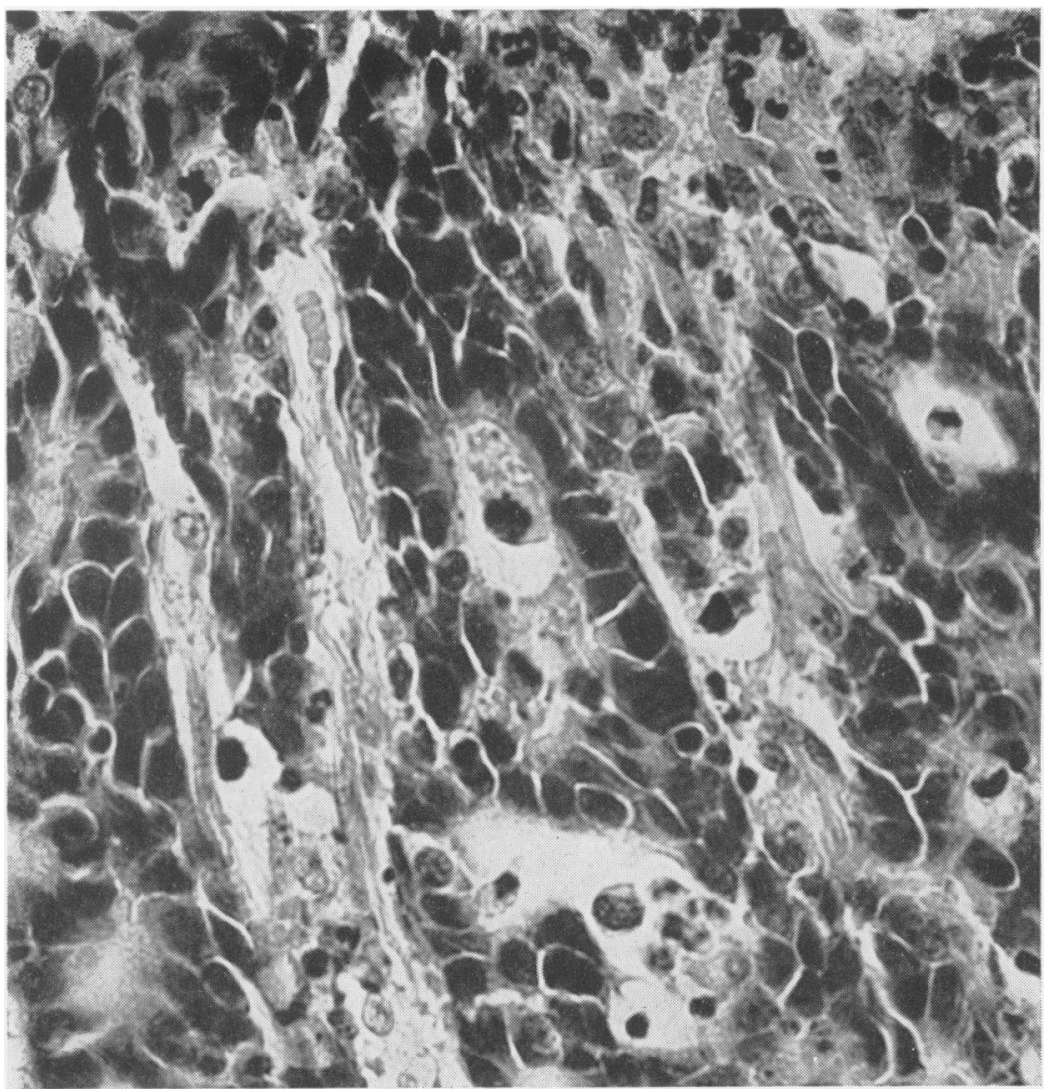

FIG. 4. High-power view of the carcinomatous area in Figure $3(\times 550)$.

FIG. 5. Surface carcinoma in the superficial zone of the mucosa. Some dilated glands are seen beneath (case 6) ( 150$)$.

FIG. 5 


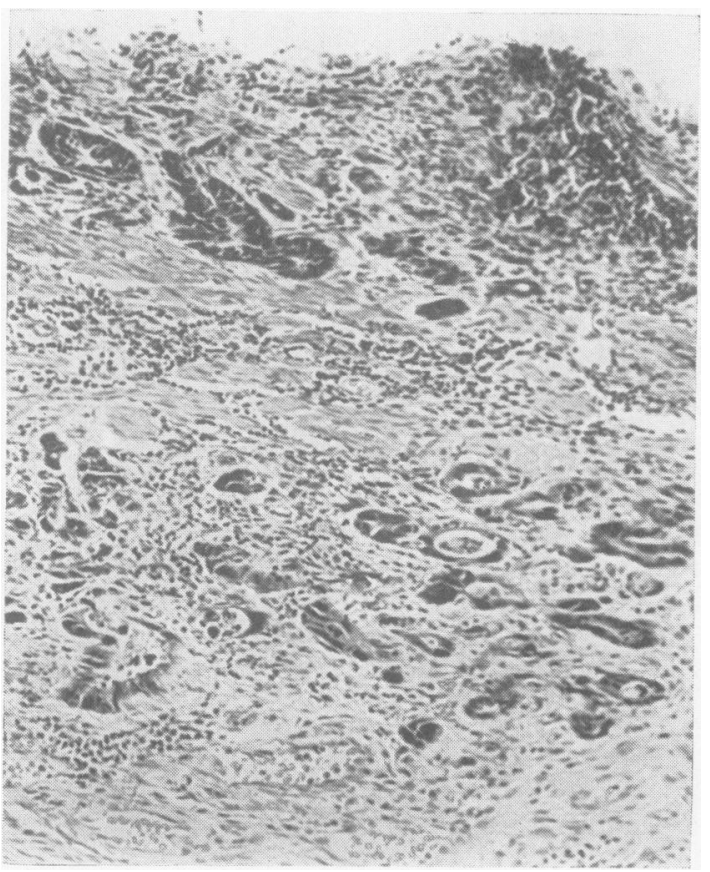

FIG. 6

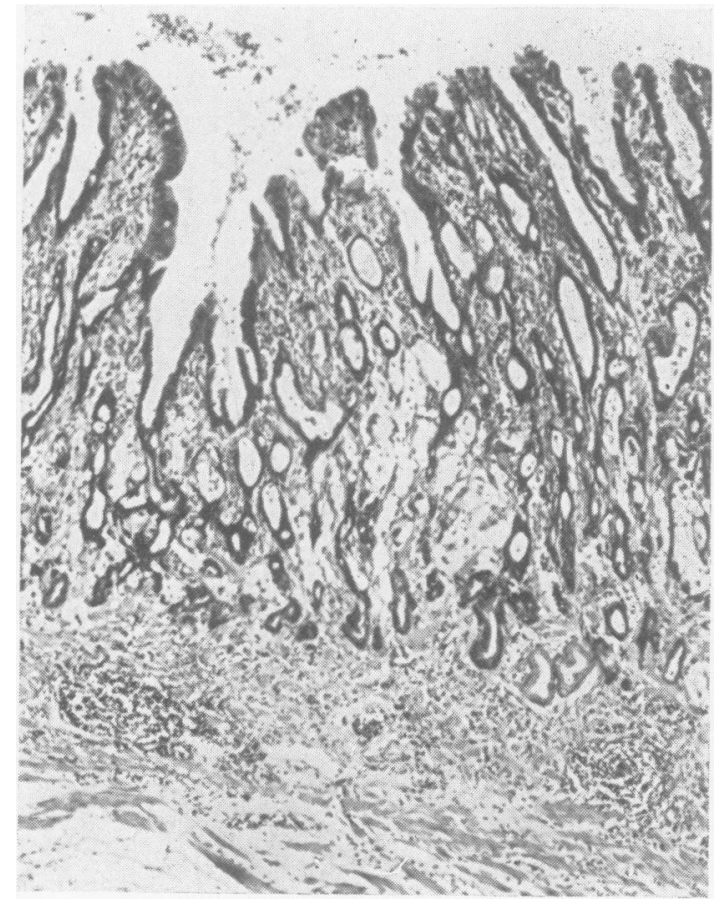

FIG. 7

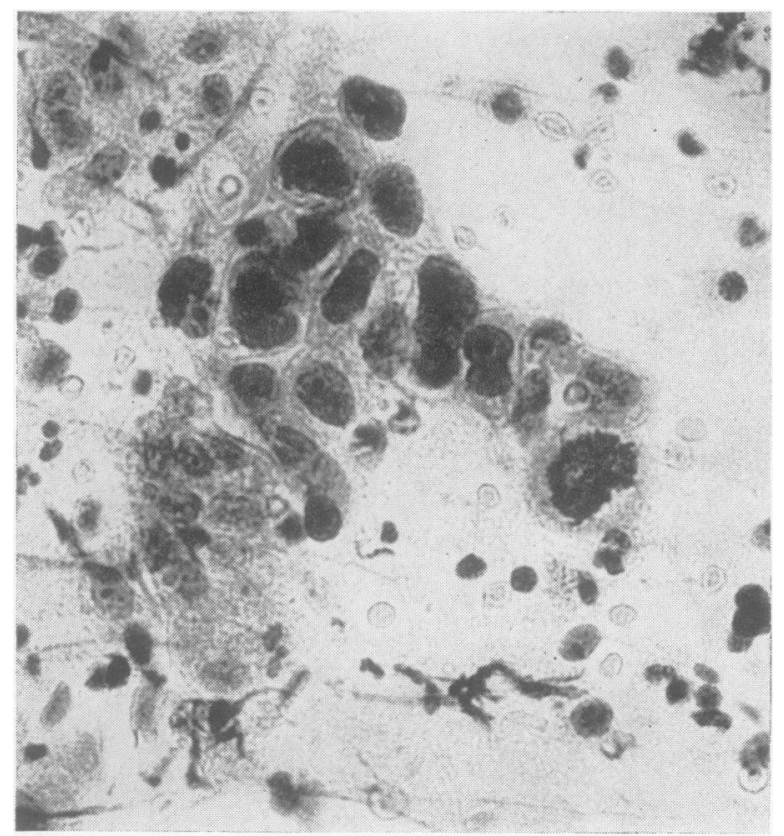

FIG. 8
FIG. 6. A grossly thinned mucosa replaced by surface carcinoma. There is invasion deep to the muscularis mucosae (case 1$)(\times 145)$.

FIG. 7. A group of cells obtained by scraping the gastric mucosa in an area of surface carcinoma, showing the typical features of malignancy (case 1) $(\times 550)$.

FIG. 8. A mucoid surface carcinoma. The lesion involves the whole thickness of the mucosa (case 12) $(\times 70)$. 
TABLE I

BENIGN GASTRIC ULCER AND ADJACENT SURFACE CARCINOMA

\begin{tabular}{|c|c|c|c|c|c|c|c|c|c|c|c|}
\hline \multirow[t]{3}{*}{ Case } & \multicolumn{4}{|c|}{ Main Clinical Features } & \multicolumn{6}{|l|}{ Specimen } & \multirow[t]{3}{*}{ Course } \\
\hline & \multirow[t]{2}{*}{$\operatorname{Sex}$} & \multirow[t]{2}{*}{ Age } & \multirow[t]{2}{*}{ Symptoms } & \multirow[t]{2}{*}{ Barium Meal } & \multicolumn{2}{|c|}{ Macroscopic } & \multicolumn{4}{|l|}{ Microscopic } & \\
\hline & & & & & $\begin{array}{l}\text { Distance } \\
\text { of Ulcer } \\
\text { from } \\
\text { Pylorus } \\
\text { (cm.) }\end{array}$ & $\begin{array}{l}\text { Size of } \\
\text { Ulcer } \\
(\mathrm{cm} .)\end{array}$ & $\begin{array}{l}\text { Adeno- } \\
\text { carcinoma }\end{array}$ & Invasion & $\begin{array}{l}\text { Depth of Mucosa } \\
\text { Involved by } \\
\text { Neoplasm }\end{array}$ & $\begin{array}{l}\text { Area Involved } \\
\text { by Carcinoma } \\
(\mathrm{cm} .)\end{array}$ & \\
\hline 1 & $\mathbf{M}$ & 54 & $\begin{array}{l}\text { Epigastric pain } \\
\text { after meals, } 15 \\
\text { years. Worse } \\
3 \text { mth. Old gastro- } \\
\text { enterostomy }\end{array}$ & $\begin{array}{l}\text { Gastroenter- } \\
\text { ostomy; no ulcer } \\
\text { seen }\end{array}$ & $\begin{array}{l}\text { Two } \\
\text { ulcers } \\
\text { each } 7 \cdot 0\end{array}$ & $\begin{array}{l}\text { Each } 0.5 \\
\text { chronic }\end{array}$ & $\begin{array}{l}\text { Poorly } \\
\text { differentiated }\end{array}$ & $\begin{array}{l}\text { Into sub- } \\
\text { mucosa }\end{array}$ & $\begin{array}{l}\text { Mainly whole } \\
\text { thickness }\end{array}$ & $\begin{array}{l}5.0 \times 4.0 \\
\text { Multifocal }\end{array}$ & $\begin{array}{l}\text { Alive and well } \\
6 \text { years }\end{array}$ \\
\hline 2 & $\mathbf{M}$ & 43 & $\begin{array}{l}\text { Epigastric pain } \\
\text { after meals, } 4 \mathrm{mth} \text {. } \\
\text { Vomiting. }\end{array}$ & Prepyloric ulcer & $1 \cdot 0$ & $\begin{array}{l}1 \cdot 0 \\
\text { chronic }\end{array}$ & $\begin{array}{l}\text { Poorly } \\
\text { differentiated }\end{array}$ & None & $\begin{array}{l}\text { Mainly } \\
\text { superficial zone }\end{array}$ & $\begin{array}{l}3.0 \times 3.5 \\
\text { Multifocal }\end{array}$ & $\begin{array}{l}\text { Alive and well } \\
5 \frac{1}{2} \text { years }\end{array}$ \\
\hline 3 & $\mathbf{M}$ & 56 & $\begin{array}{l}\text { Epigastric pain } \\
\text { after meals, } 6 \text { yr. } \\
\text { Worse recently }\end{array}$ & $\begin{array}{l}\text { Prepyloric lesion, } \\
\text { probably benign }\end{array}$ & $1 \cdot 0$ & $\begin{array}{l}1.0 \text { sub- } \\
\text { acute }\end{array}$ & $\begin{array}{l}\text { Poorly } \\
\text { differentiated }\end{array}$ & None & $\begin{array}{l}\text { Partly whole } \\
\text { thickness, partly } \\
\text { superficial zone }\end{array}$ & $\begin{array}{l}4.0 \times 3 \cdot 0 \\
\text { Multifocal }\end{array}$ & $\begin{array}{l}\text { Died carcinoma } \\
\text { of bronchus } \\
2 \text { years later }\end{array}$ \\
\hline 4 & $\mathbf{M}$ & 58 & $\begin{array}{l}\text { Epigastric pain } \\
\text { after meals, } 2 \text { yr. }\end{array}$ & $\begin{array}{l}\text { Benign gastric } \\
\text { ulcer }\end{array}$ & $5 \cdot 0$ & $\begin{array}{l}2.0 \times 1.0 \\
\text { chronic }\end{array}$ & $\begin{array}{l}\text { Poorly } \\
\text { differentiated, } \\
\text { partly } \\
\text { mucoid }\end{array}$ & $\begin{array}{l}\text { Into sub- } \\
\text { mucosa }\end{array}$ & $\begin{array}{l}\text { Mainly whole } \\
\text { thickness, partly } \\
\text { superficial zone }\end{array}$ & $\begin{array}{l}3.5 \times 3.0 \\
\text { Multifocal }\end{array}$ & $\begin{array}{l}\text { Alive and well } \\
4 \text { years }\end{array}$ \\
\hline 5 & $\mathbf{M}$ & 46 & $\begin{array}{l}\text { Epigastric pain, } \\
\text { vomiting, } \\
\text { flatulence, } 4 \text { years. } \\
\text { Worse } 1 \text { year }\end{array}$ & Prepyloric ulcer & $\begin{array}{l}\text { Pre- } \\
\text { pyloric }\end{array}$ & $\begin{array}{l}2.0 \times 3.0 \\
\text { subacute }\end{array}$ & $\begin{array}{l}\text { Poorly } \\
\text { differentiated }\end{array}$ & $\begin{array}{l}\text { Into sub- } \\
\text { mucosa }\end{array}$ & $\begin{array}{l}\text { Mainly whole } \\
\text { thickness }\end{array}$ & $\begin{array}{l}3.5 \times 5.0 \\
\text { No free areas }\end{array}$ & $\begin{array}{l}\text { Alive and well } \\
4 \text { years }\end{array}$ \\
\hline 6 & $\mathbf{M}$ & 51 & $\begin{array}{l}\text { Epigastric pain } \\
\text { after meals, } 22 \\
\text { years. Worse } \\
9 \mathrm{mth} .\end{array}$ & $\begin{array}{l}\text { Nothing abnormal } \\
\text { seen }\end{array}$ & $5 \cdot 0$ & $\begin{array}{l}1 \cdot 0 \\
\text { chronic }\end{array}$ & $\begin{array}{l}\text { Poorly } \\
\text { differentiated }\end{array}$ & $\begin{array}{l}\text { Afferent } \\
\text { vessel of } \\
\text { lymph } \\
\text { node }\end{array}$ & $\begin{array}{l}\text { Mainly whole } \\
\text { thickness, partly } \\
\text { superficial zone }\end{array}$ & $\begin{array}{l}3.0 \times 3.5 \\
\text { Multifocal }\end{array}$ & $\begin{array}{l}\text { Alive and well } \\
2 \frac{1}{2} \text { years }\end{array}$ \\
\hline 7 & $\mathbf{M}$ & 67 & $\begin{array}{l}\text { Epigastric pain, } \\
\text { anorexia, } 6 \text { weeks }\end{array}$ & $\begin{array}{l}\text { Benign gastric } \\
\text { ulcer and prepyloric } \\
\text { filling defect }\end{array}$ & $5 \cdot 0$ & $\begin{array}{l}2 \cdot 0 \\
\text { chronic }\end{array}$ & $\begin{array}{l}\text { Poorly } \\
\text { differentiated }\end{array}$ & None & $\begin{array}{l}\text { Mainly super- } \\
\text { ficial zone, partly } \\
\text { deepest zone }\end{array}$ & $\begin{array}{l}6.5 \times 4.0 \\
\text { Multifocal }\end{array}$ & $\begin{array}{l}\text { Alive and well } \\
2 \text { years }\end{array}$ \\
\hline 8 & $\mathbf{M}$ & 50 & $\begin{array}{l}\text { Indigestion many } \\
\text { years, sudden } \\
\text { haematemesis }\end{array}$ & None & $\begin{array}{l}\text { Two } \\
\text { ulcers } \\
\text { each } 5 \cdot 0\end{array}$ & $\begin{array}{l}1.0 \text { and } 0.5 \\
\text { chronic }\end{array}$ & $\begin{array}{l}\text { Poorly } \\
\text { differentiated, } \\
\text { partly } \\
\text { mucoid }\end{array}$ & None & $\begin{array}{l}\text { Mainly middle } \\
\text { zone, partly } \\
\text { deepest zone }\end{array}$ & $\begin{array}{l}6.5 \times 3.5 \\
\text { Multifocal }\end{array}$ & $\begin{array}{l}\text { Emergency } \\
\text { gastrectomy, } \\
\text { died on table }\end{array}$ \\
\hline
\end{tabular}

both ulcer, as would be expected, and carcinoma are on or near the lesser curve. The carcinoma is situated in the vicinity of the ulcer and may be present at its margin but separate foci of growth are also found away from the edge (Fig. 1). The ulcer in these cases shows all the typical features of a benign lesion as described by Stewart (1955) and Beasley (1960). Some cases may show evidence of healing in the form of stellate scarring. It is important in this group not to mistake a surface carcinoma for cellular atypicality at the edge of an ulcer.

In the second group (Table II) either no ulcer is present or if there is one it is primarily malignant in nature. In this series, all the lesions in this group were prepyloric in situation. Surface carcinoma at the periphery of an obviously infiltrating growth is well recognized but the two cases in which malignant ulceration had occurred were included because its malignant nature could not be recognized except by histological examination and the bulk of the lesion was intramucosal alone.

SPREAD OF GROWTH The multifocal origin of at least some of these tumours demonstrates that an intrinsic change is occurring in the glandular epithelium. The histological appearances in areas where growth is present only in the most superficial portion of the epithelium suggest that the tumour is arising de novo from the cells in the necks of the glands (Fig. 9). In these cases there may be dilated glands in the mucosa deep to the tumour (Fig. 5). On the other hand, when the surface carcinoma is involving the deepest zone of the mucosa only, the histology suggests that true infiltration of the interstitial tissue is occurring with normal glandular tissue still surviving at this stage (Fig. 10). In no case was there evidence of growth involving the body mucosa and all the lesions were confined to the pyloric mucosa.

Evidence of early invasion, with growth extending through the muscularis mucosae may be found (Fig. 6), or extension into the muscle may be present at the site of a primary malignant ulcer. 'Microinvasion' through the muscularis mucosae is usually found away from the edge of any benign ulcer. In four cases tumour cells were also found in the regional lymph nodes. In one of these (case 6), the stomach showed no evidence of local invasion 


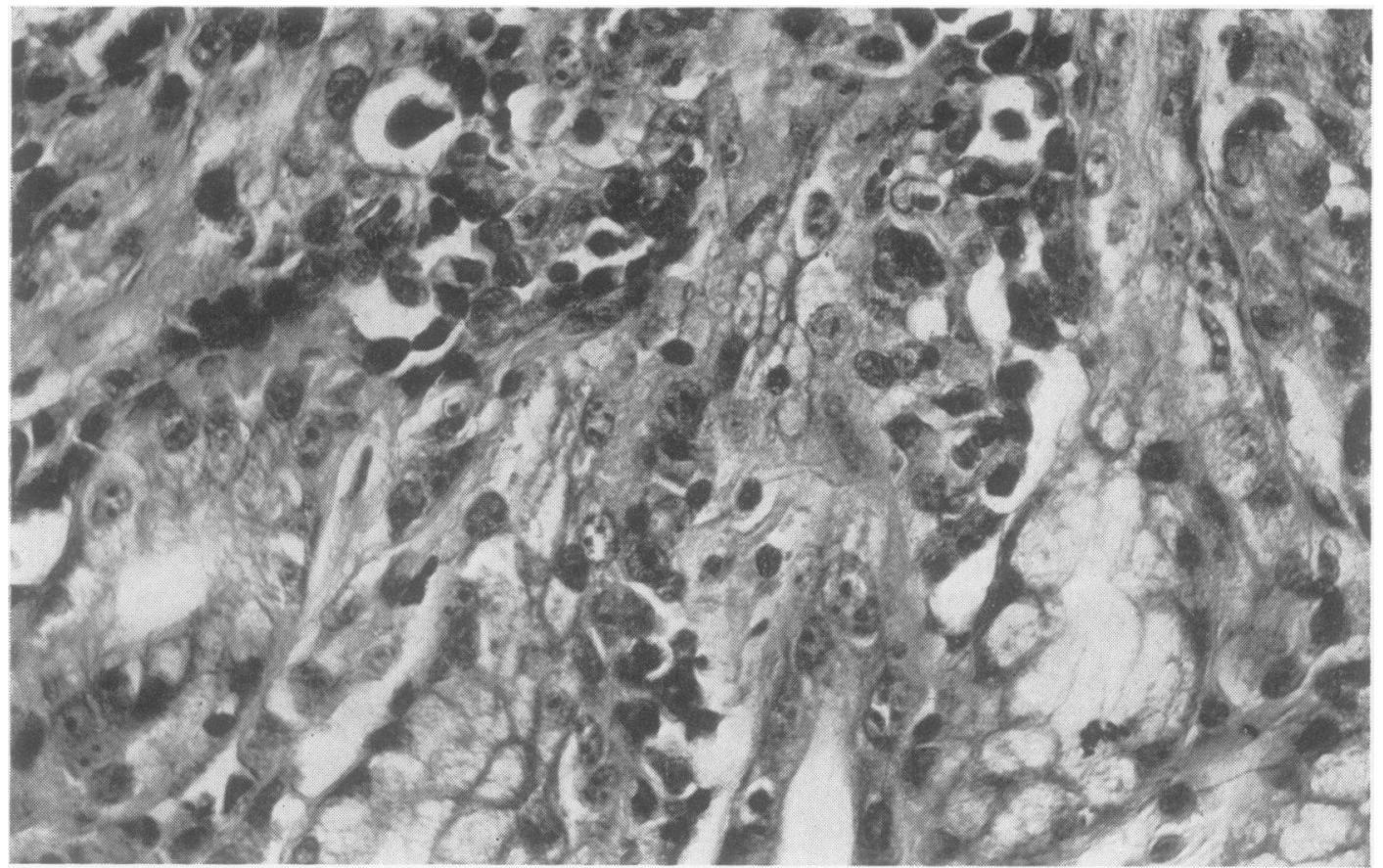

FIG. 9. High-power view of a surface carcinoma in the superficial zone of the mucosa only. The lesion appears to be arising from the glands (case 11) $(\times 500)$.

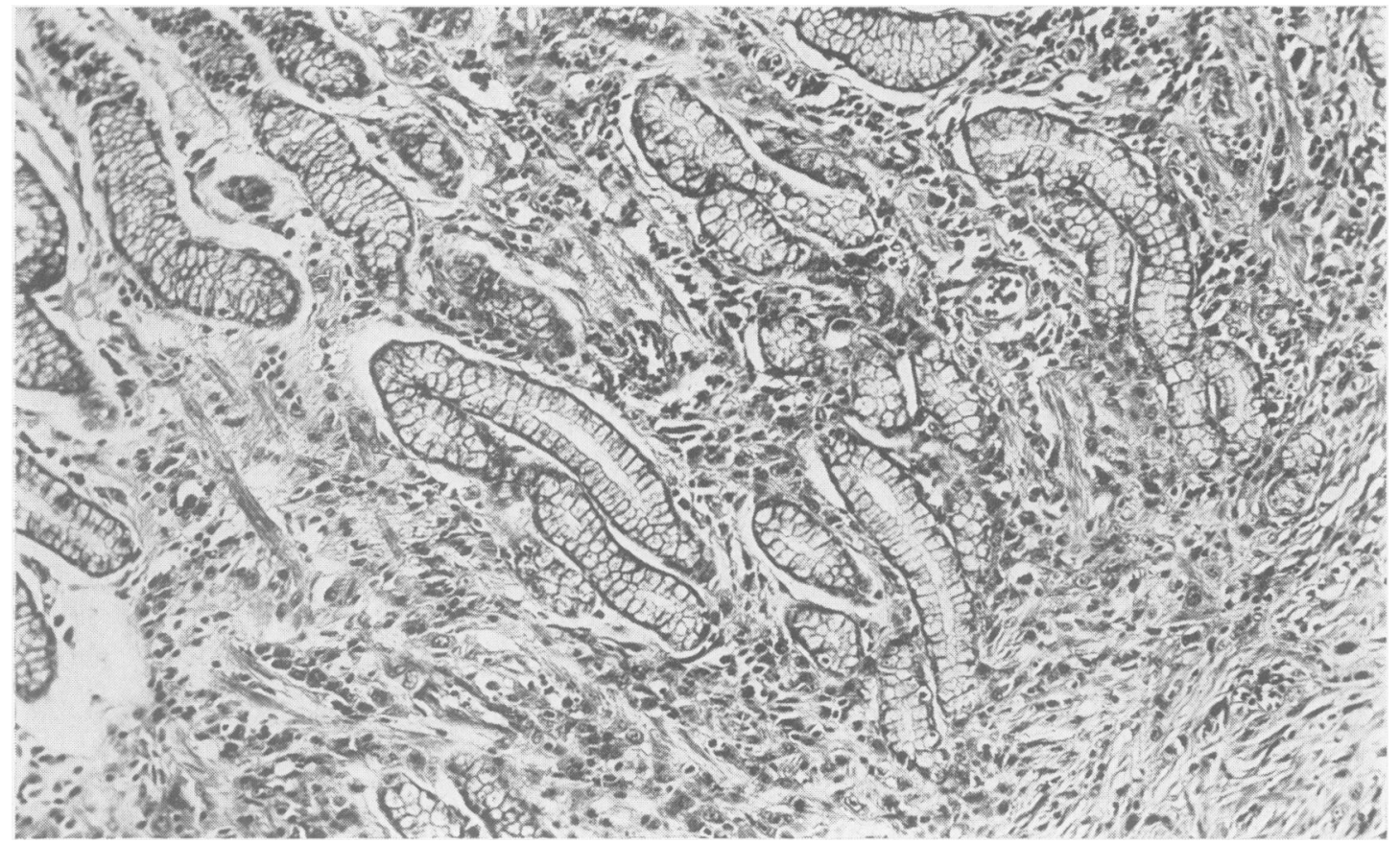

FIG. 10. Another area from the same case as Fig. 9 showing a surface carcinoma in the deepest zone of the mucosa. Growth is present in the interstitial tissue while the glands appear free. An occasional malignant cell is seen in the muscularis mucosae $(\times 150)$. 
TABLE II

SURFACE CARCINOMA WITHOUT ASSOCIATED BENIGN GASTRIC ULCER

\begin{tabular}{|c|c|c|c|c|c|c|c|c|c|c|}
\hline \multirow[t]{3}{*}{ Case } & \multicolumn{4}{|c|}{ Main Clinical Features } & \multicolumn{5}{|l|}{ Specimen } & \multirow[t]{3}{*}{ Course } \\
\hline & \multirow[t]{2}{*}{ Sex } & \multirow[t]{2}{*}{ Age } & \multirow[t]{2}{*}{ Symptoms } & \multirow[t]{2}{*}{ Barium Meal } & \multirow[t]{2}{*}{ Macroscopic } & \multicolumn{4}{|l|}{ Microscopic } & \\
\hline & & & & & & $\begin{array}{l}\text { Adeno- } \\
\text { carcinoma }\end{array}$ & Invasion & $\begin{array}{l}\text { Depth of } \\
\text { Mucosa } \\
\text { Involved } \\
\text { by Surface } \\
\text { Neoplasm }\end{array}$ & $\begin{array}{l}\text { Area Involved } \\
\text { by Carcinoma } \\
\text { (cm.) }\end{array}$ & \\
\hline 9 & $\mathbf{M}$ & 62 & $\begin{array}{l}\text { Flatulence and } \\
\text { weight loss, } 8 \mathrm{mth} \text {. }\end{array}$ & $\begin{array}{l}\text { Pyloric obstruction, } \\
\text { ? nature }\end{array}$ & $\begin{array}{l}\text { Ulcer, } 2.0 \mathrm{~cm} \text {. in } \\
\text { diameter, } 2.0 \mathrm{~cm} \text {. } \\
\text { from pylorus, thin } \\
\text { mucosa in antrum } \\
\text { for } 7 \mathrm{~cm} . \text {, nodules at } \\
\text { junction with normal } \\
\text { mucosa }\end{array}$ & $\begin{array}{l}\text { Poorly } \\
\text { differentiated, } \\
\text { partly mucoid }\end{array}$ & $\begin{array}{l}\text { Into serosa at } \\
\text { ulcer and sub- } \\
\text { mucosa adjacent; } \\
\text { mucosa only } \\
\text { elsewhere }\end{array}$ & $\begin{array}{l}\text { Whole } \\
\text { thickness }\end{array}$ & $\begin{array}{l}\mathbf{7 . 0} \times \mathbf{8 . 0} \\
\text { No free areas }\end{array}$ & 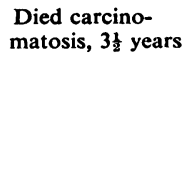 \\
\hline 10 & $0 \mathrm{~F}$ & 71 & $\begin{array}{l}\text { Anorexia and } \\
\text { weight loss, } 3 \\
\text { years }\end{array}$ & $\begin{array}{l}\text { Prepyloric filling } \\
\text { defect, probably } \\
\text { malignant }\end{array}$ & $\begin{array}{l}\text { Pyloric mucosa } \\
\text { thickened and rough; } \\
\text { no ulcer }\end{array}$ & $\begin{array}{l}\text { Poorly } \\
\text { differentiated }\end{array}$ & $\begin{array}{l}\text { Into muscle coat } \\
\text { at pylorus and } \\
\text { submucosa } \\
\text { adjacent; mucosa } \\
\text { only elsewhere. } \\
\text { Metastasis in one } \\
\text { lymph node }\end{array}$ & $\begin{array}{l}\text { Whole } \\
\text { thickness }\end{array}$ & $\begin{array}{l}3.5 \times 5.0 \\
\text { No free areas }\end{array}$ & $\begin{array}{l}\text { Died carcinoma } \\
\text { of tongue } \\
18 \mathrm{mth} \text {; no } \\
\text { evidence stomach } \\
\text { cancer }\end{array}$ \\
\hline 11 & $\mathbf{M}$ & 46 & $\begin{array}{l}\text { Epigastric pain } \\
\text { after meals, } 1 \\
\text { year }\end{array}$ & $\begin{array}{l}\text { Prepyloric ulcer: } \\
\text { probably benign }\end{array}$ & $\begin{array}{l}\text { Prepyloric ulcer, } \\
1.0 \mathrm{~cm} \text {. in diameter }\end{array}$ & $\begin{array}{l}\text { Poorly } \\
\text { differentiated }\end{array}$ & $\begin{array}{l}\text { Into muscle coat } \\
\text { at ulcer; spread } \\
\text { in submucosa }\end{array}$ & $\begin{array}{l}\text { Mainly } \\
\text { deepest } \\
\text { zone }\end{array}$ & $\begin{array}{l}5.5 \times 3.5 \\
\text { Multifocal }\end{array}$ & $\begin{array}{l}\text { Alive and well } \\
4 \text { years }\end{array}$ \\
\hline 12 & $\mathbf{M}$ & 46 & $\begin{array}{l}\text { Anorexia and } \\
\text { nausea, } 3 \text { years }\end{array}$ & $\begin{array}{l}\text { Prepyloric ulcer, } \\
\text { probably benign }\end{array}$ & $\begin{array}{l}\text { Roughened pyloric } \\
\text { antrum; no ulcer }\end{array}$ & Mucoid & None & $\begin{array}{l}\text { Mainly } \\
\text { whole } \\
\text { thickness, } \\
\text { partly } \\
\text { superficial } \\
\text { zone }\end{array}$ & $\begin{array}{l}5.0 \times 4.0 \\
\text { Multifocal }\end{array}$ & $\begin{array}{l}\text { Alive and well } \\
2 \frac{1}{2} \text { years }\end{array}$ \\
\hline
\end{tabular}

deep to the mucosa, while in the other three (cases 10,14 , and 15) some local infiltration beyond the mucosa had occurred. In every affected node, however, the tumour cells were situated in the afferent lymphatics only and no true invasion of their substance was seen.

INCIDENCE OF SURFACE CARCINOMA In 80 of the 158 stomachs removed for apparently benign conditions, the lesion was in the duodenum alone and in the remaining 78 there was a lesion in the stomach. The pre-operative diagnosis in these 78 cases was either benign gastric ulcer or prepyloric ulcer which could be malignant because of its situation. The total number of surface carcinomas in this series of specimens was eight $(10.3 \%)$, of which five were associated with a pre-existing benign gastric ulcer and the remaining three $(3.8 \%)$ formed part of a primary malignant condition in the prepyloric region. The proportion of surface carcinomas with a benign gastric ulcer was therefore $6.4 \%$. In the entire group of gastric and duodenal ulcers combined (158 cases) a surface carcinoma was found in $5.1 \%$.

\section{CLINICAL FEATURES}

The main clinical features in the patients are briefly summarized in the tables. The most striking feature in the 'benign ulcer' group was the long history, varying from two to 22 years. There were two exceptions with a history of under four months. Recent alteration or exacerbation of symptoms was a common complaint in these patients. By contrast, the history did not exceed three years in any of the four cases with no pre-existing ulcer. There was a marked preponderance of males in both groups. The average age at the time of operation was 53 years for the first group and 56 years for the second, with nearly half the patients in the entire series under 50 years of age.

In none of the patients was a firm diagnosis of carcinoma made from the radiological appearances. The $x$-ray findings were either those of benign ulceration or the possibility of carcinoma was considered only because there was a prepyloric lesion.

The lesions were thought to be benign at laparotomy except in one instance (case 9).

\section{DISCUSSION}

Surface carcinomas are not uncommon in stomachs excised for an apparently benign condition. There seems little doubt that they represent an early stage in the natural history of a developing gastric carcinoma. They are found at an earlier age than invasive tumours, 53 years both in this series and that of 
Friesen et al. (1962), against an average of 60 years for clinically apparent cases (Harnett, 1952). There is also undoubted evidence in some cases of an early stage of invasion. Surface carcinomas, however, should not be regarded as 'in situ' lesions. A true carcinoma in situ is confined within the basement membrane of the glands, whereas these lesions involve the interstitial tissue as well. True carcinoma in situ is a very rare finding, but cases have been reported by Bamforth (1955) and by Bocian and Geschke (1958). In Bamforth's case, the lesion was situated in the surface glands and there is some evidence from the present study that some at least of the gastric carcinomas start in the most superficial part of the mucosa rather than in the more specialized deeper glands. One can only guess at the time taken for a surface carcinoma to become actively invasive but the age differential suggests that it is several years.

RELATIONSHIP TO CHRONIC SIMPLE ULCERS The present study fully confirms the conclusions of others that gastric carcinomas are commonly multifocal in origin (Collins and Gall, 1952; Moertel, Bargen, and Soule, 1957; Friesen et al., 1962). Stewart (1955) and Beasley (1960), in studies of more advanced cases, considered that a considerable proportion of cancers originate in simple chronic ulcers, but in this series of early cases separate foci of carcinoma were found away from the ulcer in all but one. In none could the lesions be regarded as true 'ulcer-cancers'. Helsingen and Hillestad (1956) found a greatly increased incidence of gastric carcinomas developing in patients who had earlier undergone partial gastrectomy for a benign gastric ulcer but not in patients operated on for duodenal ulcer. These findings suggest that stomachs liable to develop a gastric ulcer are also liable to develop a carcinoma, a view also taken by Swynnerton and Tanner (1953). It was found by Dean and Mason (1964) that some pyloric mucosa was left behind in $39.0 \%$ of patients in whom a gastrectomy was performed for a simple gastric ulcer. Since surface carcinomas and gastric ulcers are both lesions of the pyloric mucosa there would appear to be a good case for a higher gastrectomy in patients with apparently simple ulcers. It is important for the pathologist to take a longitudinal section of all gastric ulcers and, if a surface tumour is found, to section further areas and particularly the upper cut edge of the specimen on the lesser curve.

PRIMARY SURFACE CARCINOMAS It is of interest that in the four cases where there was no evidence of pre-existing simple ulceration the lesions should all have been arising in the prepyloric region. This may merely reflect the fact that this is the commonest site for carcinoma, or it may be because lesions in

TABLE III

PREVIOUS CASES OF BENIGN GASTRIC ULCERATION WITH SURFACE CARCINOMA

\begin{tabular}{|c|c|c|c|c|c|c|c|c|c|c|}
\hline \multirow[t]{3}{*}{ Case } & \multicolumn{4}{|c|}{ Main Clinical Features } & \multicolumn{5}{|l|}{ Specimen } & \multirow[t]{3}{*}{ Course } \\
\hline & \multirow[t]{2}{*}{ Sex } & \multirow[t]{2}{*}{ Age } & \multirow[t]{2}{*}{ Symptoms } & \multirow[t]{2}{*}{ Barium Meal } & \multicolumn{2}{|l|}{ Macroscopic } & \multicolumn{3}{|l|}{ Microscopic } & \\
\hline & & & & & $\begin{array}{l}\text { Distance of Ulcer } \\
\text { from Pylorus }(\mathrm{cm} .)\end{array}$ & $\begin{array}{l}\text { Size of Ulcer } \\
(\mathrm{cm} .)\end{array}$ & Adenocarcinoma & Invasion & $\begin{array}{l}\text { Depth of } \\
\text { Mucosa } \\
\text { Involved by } \\
\text { Neoplasm }\end{array}$ & \\
\hline 13 & $\mathbf{M}$ & 40 & $\begin{array}{l}\text { Epigastric pain } \\
\text { after meals, } 2 \\
\text { years }\end{array}$ & $\begin{array}{l}\text { Gastric ulcer, } \\
\text { probably benign }\end{array}$ & $1 \cdot 5$ & $1 \cdot 0$ & $\begin{array}{l}\text { Poorly } \\
\text { differentiated }\end{array}$ & $\begin{array}{l}\text { Into } \\
\text { muscle } \\
\text { coat } \\
\text { adjacent } \\
\text { to ulcer }\end{array}$ & $\begin{array}{l}\text { Whole } \\
\text { thickness }\end{array}$ & $\begin{array}{l}\text { Alive and } w \\
10 \text { years }\end{array}$ \\
\hline 14 & $\mathbf{M}$ & 56 & $\begin{array}{l}\text { Epigastric pain, } \\
3 \text { years }\end{array}$ & $\begin{array}{l}\text { Prepyloric gastric } \\
\text { ulcer, probably } \\
\text { benign; some } \\
\text { stenosis }\end{array}$ & $1 \cdot 0$ & $2 \cdot 0$ & $\begin{array}{l}\text { Poorly } \\
\text { differentiated }\end{array}$ & $\begin{array}{l}\text { Into } \\
\text { muscle } \\
\text { coat } \\
\text { adjacent } \\
\text { to ulcer; } \\
\text { meta- } \\
\text { stases in } \\
4 \text { lymph } \\
\text { nodes }\end{array}$ & $\begin{array}{l}\text { Mainly } \\
\text { superficial } \\
\text { zone }\end{array}$ & $\begin{array}{l}\text { Alive and } w \\
9 \text { years }\end{array}$ \\
\hline 15 & $\mathbf{M}$ & 46 & $\begin{array}{l}\text { Indigestion, } 20 \\
\text { years. Worse } 1 \\
\text { year }\end{array}$ & $\begin{array}{l}\text { Benign gastric } \\
\text { ulcer }\end{array}$ & $3 \cdot 0$ & $3 \cdot 0$ & $\begin{array}{l}\text { Poorly } \\
\text { differentiated }\end{array}$ & $\begin{array}{l}\text { Into sub- } \\
\text { mucosa. } \\
\text { Meta- } \\
\text { stases in } \\
7 \text { lymph } \\
\text { nodes; } \\
\text { growth at } \\
\text { upper end } \\
\text { of } \\
\text { specimen }\end{array}$ & $\begin{array}{l}\text { Mainly } \\
\text { whole } \\
\text { thickness }\end{array}$ & $\begin{array}{l}\text { Died } 8 \text { years } \\
\text { carcinomato } \\
\text { probably fro } \\
\text { primary of } \\
\text { bronchus }\end{array}$ \\
\hline
\end{tabular}


this region may be expected to produce symptoms and also $x$-ray changes earlier.

PROGNOSIS A striking feature is the good prognosis, particularly in patients with pre-existing ulcers. Kuhlencordt (1959) in a long-term follow-up found survival with surface lesions of up to 15 years, with no deaths from gastric carcinoma. The patients in the present series have been followed for periods between two and a half and 10 years with only one death from gastric cancer. By contrast, the threeyear survival rate for patients with obvious gastric carcinomas is $30.0 \%$ (Daoud, 1964). It is remarkable that, even with tumour in the regional lymph nodes, there has been a long survival with carcinomas which were otherwise largely intramucosal (Table III). It is perhaps significant that the malignant cells in these cases were in the afferent lymphatics only and not actively replacing the node. Why a tumour should be invasive in a stomach and apparently dormant in the related lymphatics remains obscure. Nevertheless, as shown by Kuhlencordt (1959) and by Brown, Cain, and Dockerty (1961), the prognosis in these cases must be more cautious when there is extension beyond the mucosa.

CLINICAL DIAGNOSIS The clinical diagnosis of a surface carcinoma is very difficult. Recent alteration of symptoms in a patient with a long-standing gastric ulcer may make the clinician suspect malignancy but investigations are unlikely to help and $x$-ray findings in particular are inconclusive (Golden and Stout, 1948).

The histological diagnosis of surface carcinoma depends largely on the cytological appearances of the cells in the malignant areas and Schade (1958) has had considerable success by employing cytological techniques to diagnose these lesions preoperatively. No malignant cells were obtained, however, when pre-operative gastric lavage was performed on two patients in this series. For the present, therefore, one may have to fall back on considering partial gastrectomy in patients over 40 years of age with a longstanding gastric ulcer who have had a recent alteration in symptoms, and ensuring that an adequate gastrectomy is done with removal of all pyloric mucosa. A rapid frozen section at the time of operation might sometimes prove of great help in deciding the diagnosis and an adequate histological study of the stomach after removal is essential in all cases.

\section{SUMMARY}

Surface carcinomas in which the lesion was confined, or almost confined, to the mucosa were found in
$10.3 \%$ of stomachs removed for apparently benign gastric lesions. The pathological features of these carcinomas are described. Surface carcinomas were most often found in stomachs in which there was a pre-existing benign gastric ulcer but the findings suggested that they were essentially independent lesions and did not represent malignant change in the ulcer. Even with local early invasion or with tumour cells in the afferent lymphatics of regional lymph nodes, there is generally a good prognosis when a surface carcinoma is found in a partial gastrectomy specimen.

I would like to thank Professor H. A. Magnus and Dr. J. Bamforth for their advice and encouragement. Cases 7 and 8 were made available through the courtesy of Dr. F. Dische. I am most grateful to the British Empire Cancer Campaign for Research, who provided a grant which enabled this work to be undertaken. The photomicrographs were taken by Mr. G. Harwood and Mr. E. V. Wilmott.

\section{REFERENCES}

Bamforth, J. (1955). Early carcinomatous changes in the stomach. Brit. J. Surg., 43, 292-296.

Beasley, W. H. (1960). The blood groups of gastric ulcer-cancer. J. clin. Path., 13, 315-324.

Bocian, J. J., and Geschke, A. E. (1958). Carcinoma in situ of the stomach. Arch. Path., 65, 6-12.

Brown, P. M., Cain, J. C., and Dockerty, M. B. (1961). Clinically 'benign' gastric ulcerations found to be malignant at operation. Surg. Gynec. Obstet., 112, 82-88.

Collins, W. T., and Gall, E. A. (1952). Gastric carcinoma: a multicentric lesion. Cancer (Philad.), 5, 62-72.

Daoud, E. H. (1964). The prognostic significance of sinus histiocytosis in regional lymph nodes and of the local presence of round cells in human cancer. Ph.D. Thesis, London.

Dean, A. C. B., and Mason, M. K. (1964). The distribution of pyloric mucosa in partial gastrectomy specimens, Gut, 5, 64-67.

Ewing, J. (1936). The beginnings of gastric cancer. Amer. J. Surg., 31, 204-205.

Friesen, G., Dockerty, M. B., and ReMine, W. H. (1962). Superficial carcinoma of the stomach. Surgery, 51, 300-312.

Golden, R., and Stout, A. P. (1948). Superficial spreading carcinoma of the stomach. Amer. J. Roentgenol., 59, 157-167.

Gutmann, R. A. C., Bertrand, I. G., and Péristiany, T. J. (1939). Le Cancer de l'Estomac au début. G. Doin, Paris.

Harnett, W. L. (1952). A Survey of Cancer in London. (British Empire Cancer Campaign, Report of Clinical Cancer Research Committee.) B.E.C.C., London.

Helsingen, N., and Hillestad, L. (1956). Cancer development in the gastric stump after partial gastrectomy for ulcer. Ann. Surg., 143, 173-179.

Kuhlencordt, F. (1959). Das Carcinoma in situ des Magens und der kleine Magenkrebs. Dtsch. med. Wschr., 84, 2111-2115.

Magnus, H. A. (1937). Observations on the presence of intestinal epithelium in the gastric mucosa. J. Path. Bact., 44, 389-398.

Mallory, T. B. (1940). Carcinoma in situ of the stomach and its bearing on the histogenesis of malignant ulcers. Arch. Path., 30, 348-362.

Moertel, C. G., Bargen, J. A., and Soule, E. H. (1957). Multiple gastric cancers. Gastroenterology, 32, 1095-1103.

Schade, R. O. K. (1958). Exfoliative cytology of gastric carcinoma. Brit, med. J., 1, 743-744.

Stewart, M. J. (1955). Ulcer-Cancer of the Stomach. Jackson, Glasgow.

Stout, A. P. (1942). Superficial spreading type of carcinoma of the stomach. Arch. Surg., 44, 651-657.

Swynnerton, B. F., and Tanner, N. C. (1953). Chronic gastric ulcer. Brit. med. J., 2, 841-847. 